which the issue of energy policy was for the first time in Britain officially pushed into the arena of public debate.

According to its terms of reference, which were announced by $\mathrm{Mr}$ Benn in July, the commission will be concerned with two main issues: the developments of a strategy for the energy sector in the United Kingdom, and specific aspects of energy policy that arise from time to time.

On both of these, according to $\mathrm{Mr}$ Benn, the commission will "seek to form an agreed view", feeding into the process by which he hopes that the Government will eventually be able to publish annual reports on the energy situation. These would contain reviews of decisions taken, current prospects, and matters likely to come up for discussion.

As a first step, the Government is expected to publish a Green Paper on energy policy in Britain early in the new year. This will be based on a working document on energy policy which was prepared for the Energy Commission, and published by the Department of Energy last month.

The working document, which was welcomed by environmentalists as indicating slightly more tentative attitude towards energy issues than previous government statements, and reduced by 10 per cent an earlier forecast of energy needs in the UK by the year 2,000 , was one of the main items on the agenda of Monday's meeting.

Among the comments made, for example, was that little attention had been given to the problem of the availability of skilled manpower for the energy industries, a point which $\mathrm{Mr}$ Been said would, like others made at the meeting, be taken into account in the drafting of the Green Paper.

Mr Benn expressed satisfaction, however, that in line with what he calls a "consensus approach to energy policy", the members of the commission had given general support for the working document which was to form the basis of the Green Paper. "We have hit on an energy programme for December 1977 which can claim a wide measure of public consent and understanding", he said.

He emphasised, however, that the commission was purely advisory. Although it provided a chance for the various power industries to compare notes on their future programmes, there was no suggestion that the commission should take over either the responsibilities of the fuel industries, or those of the established Parliamentary and Governmental channels.

It remains to be seen whether this will be sufficient to maintain the confidence both of the nationalised industries, with their recently-expressed concerns about government "interference", or the trade union representatives, who would like a body such as the commission to assume a great executive responsibility.

Earlier this year Mr Frank Chapple, general secretary of the Electrical, Electronic, Telecommunication and Plumbing Union, and chairman of the TUC's Fuel and Power Industries Committee, six of whose members represent the trade union interest on the commission, suggested that there was a need for a body such as the commission to "bang heads together and work out mutually agreed policies".

$\mathrm{Mr}$ Chapple warned: "We are not prepared to rescue the formulation of energy policy from the short-term vagaries of the market-place only to see it taken over by bureaucrats in Whitehall and removed from the public domain."

David Dickson

simply part of a routine Union-wide patrol, or was the unfortunate Gary Powers sent to confirm reports already received from a ground-level contact?

Much more mysterious is the fact that the CIA material mentions two explosions, one in 1958 and one in 1959. It seems on the face of it unlikely that two nuclear accidents could occur in successive years-even if we admit that an atmosphere of neglect makes Soviet installations peculiarly accidentprone, the fall-out from the first disaster would have surely led to the abandonment of the area, with the shut-down of any project already operating.

Vera Rich area in 1961 and reports extensive aster. Dr Tumerman, however, will not commit himself on the cause, stating only that it could not have been an accident in an operational power station, since at that time the Soviet Union possessed no such installation. Even in 1961, the first such station, at Beloyarsk, was still in the foundationlaying and concrete mixing stage.

Dr Zhores Medvedev, who visited the area at much the same time, is convinced that the explosion occurred in a nuclear waste store. Although the storage of waste products involves a real leakage hazard, it is difficult to see how it could cause an explosion. One Russian scientist (not a nuclear physicist), told Nature that he himself felt that Medvedev's explanation was quite possible, since the Soviet regime pro-

duces in its scientists an "attitude of neglect", so that proper precautions are would, however, apply equally to an explosion at a prototype reactor plant, as much as at a waste dump.

The latest step in the enigma is posed by the release of hitherto secret documents by the CIA. Fourteen documents were released; another 15 exist but are still considered too sensitive, so that as seems typical for Kyshtym, only partial evidence is available. The involvement of the CIA itself raises a number of questions; in particular, was the notorious U-2 flight over the area

\title{
Was Tungus an astronaut?
}

SINCE the first expedition, just 50 years ago, to the site of the "Tungus event" of 1908, the explosion has posed a major riddle to geophysicists. The latest in a long line of theories, that of a certain Aleksei Zolotov, poses a further mystery-how, in the conditions prevailing in Soviet science, did it ever get published?

It is well-known that the publication of scientific articles in the Soviet Union is subject to strict controls. No paper may be submitted without a special certificate from the author's place of employment-a regulation which, it would appear, leaves no outlet for either the gifted amateur or the harm- less crank. When Soviet science has, on occasion, followed its own course, unacknowledged by the outside world, this has been due to either the party bypassing normal academic procedures - as in the case of Lysenko-or else to the initiative of the topmost echelons of the scientific establishment-as with the blanket denial of ocean-floor spreading, or Snezhnevskii's theory of "creeping schizophrenia".

Recently, however, Moscow radio broadcast in both Russian and English a "new explanation" of the Tungus "enigma". The theory itself is not new to Western readers of fringe publications: the devastation, it is claimed, 